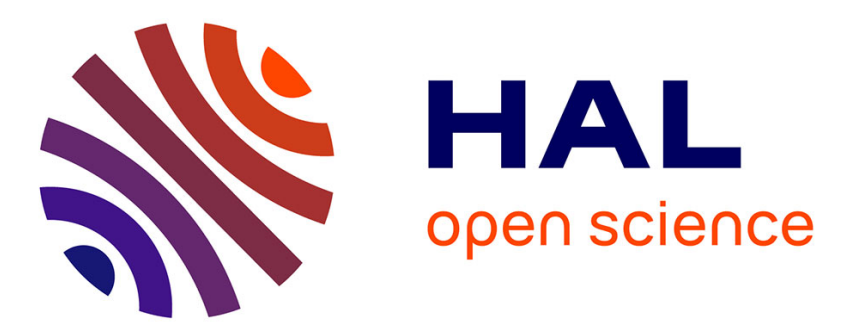

\title{
Potentiometric study of vitamin D3 complexes with manganese(II), iron(II), iron(Ill) and zinc(II) in water-ethanol medium
}

\author{
A.L.R Mercê, B Szpoganicz, M A Khan, X Do Than, G Bouet
}

\section{To cite this version:}

A.L.R Mercê, B Szpoganicz, M A Khan, X Do Than, G Bouet. Potentiometric study of vitamin D3 complexes with manganese(II), iron(II), iron(Ill) and zinc(II) in water-ethanol medium. Journal of Inorganic Biochemistry, 1999, 73 (3), pp.167-172. 10.1016/s0162-0134(99)00014-8 . hal-03199232

\section{HAL Id: hal-03199232 \\ https://univ-angers.hal.science/hal-03199232}

Submitted on 16 Apr 2021

HAL is a multi-disciplinary open access archive for the deposit and dissemination of scientific research documents, whether they are published or not. The documents may come from teaching and research institutions in France or abroad, or from public or private research centers.
L'archive ouverte pluridisciplinaire HAL, est destinée au dépôt et à la diffusion de documents scientifiques de niveau recherche, publiés ou non, émanant des établissements d'enseignement et de recherche français ou étrangers, des laboratoires publics ou privés. 


\title{
Potentiometric study of vitamin $\mathrm{D}_{3}$ complexes with manganese(II), iron(II), iron(III) and zinc(II) in water-ethanol medium
}

\author{
A.L.R. Mercê ${ }^{\mathrm{a}}$, B. Szpoganicz ${ }^{\mathrm{b}}$, M.A. Khan ${ }^{\mathrm{c}}$, X. Do Thanh ${ }^{\mathrm{d}}, \mathrm{G}$ Bouet $^{\mathrm{c}, *}$ \\ a Departamento de Quimica, Centro Politécnico, Paraná, CP 19081, CEP 81531-990 Curitiba, PR, Brazil \\ 'UFSC, Departamento de Quimica, Campus Universiário, Trindade, CP 476, CEP 88040-900 Florianópolis, SC, Brazil \\ ${ }^{\mathrm{c}}$ Chimie de Coordination, Faculté de Pharmacie, 16 Boulevard Daviers, F-49100 Angers, France \\ ${ }^{d}$ Physiologie-Pharmacologie. Faculté de Pharmacie, 16 Boulevard Daviers, F-49100 Angers, France
}

Received 20 October 1998; received in revised form 14 January 1999; accepted 15 January 1999

\begin{abstract}
Vitamin $\mathrm{D}_{3}$ (LH) complexes with manganese(II), iron(II), iron(III) and zinc(II) were identified in water-ethanol medium (30/70). Their stability constants were determined at $298 \mathrm{~K}$ and at a constant ionic strength of $0.100 \mathrm{M}$ using potentiometric methods. The computerisation of the experimental data showed the presence of $\mathrm{ML}\left(\mathrm{M}=\right.$ metal, $\mathrm{L}=$ deprotonated vitamin $\left.\mathrm{D}_{3}\right)$ and $\mathrm{ML}_{2}$ species in all cases; in addition, the $\mathrm{ML}_{3}$ iron(III) complex was detected. The calculated overall stability constants $\beta$ for $\mathrm{Mn}^{\mathrm{II}} \mathrm{L}, \mathrm{Fe}^{\mathrm{II}} \mathrm{L}, \mathrm{Fe}^{\mathrm{III}} \mathrm{L}$ and $\mathrm{Zn}{ }^{\mathrm{II}} \mathrm{L}$ are, respectively, in logarithms, $12.4,16.5,28.5$ and 16.5. Under the experimental conditions, the only protonated species MLH detected was with iron(III). (C) 1999 Elsevier Science Inc. All rights reserved.
\end{abstract}

Keywords: Potentiometry; Vitamen $\mathrm{D}_{3}$ metallic complexes; Water-ethanol

\section{Introduction}

Many metallic cations are involved in human metabolism as well as in oligotherapy. For instance, transition metal ions such as manganese(II), iron(II), cobalt(II) or zinc(II) give higher enzymatic activity levels compared to magnesium (II) for some native and mutant enzymes with $\mathrm{Mg}^{2+}$ as natural cofactor [1]. Zinc(II), cadmium(II), cobalt(II) and magnesium( II) could readily bind to apoalkaline phosphatase of Escherichia coli at various sites, leading to different effects upon the activity of the enzyme [2].

In a previous article [3], we determined the stability constants of vitamin $D_{3}$ (vitD) or cholecalciferol complexes involving cobalt(II), nickel(II) and copper(II) in waterethanol medium.

In the present paper, we describe the results of the complexation of vitD with manganese(II), iron(II), iron(III) and zinc(II) in water-ethanol medium at $298 \mathrm{~K}$ and at a constant ionic strength $(0.100 \mathrm{M})$. Usually, both potentiometric and spectrophotometric techniques could be used for computerised determinations. In the case of vitD, its insta-

\footnotetext{
*Corresponding author. Fax: +33-241-486-733; E-mail: gilles.bouet@ univ-angers.fr
}

bility in aqueous solution and to light exposure did not allow us to perform spectrophotometric measurements. The complexes were identified potentiometrically and their respective formation constants were calculated.

\section{Experimental}

\subsection{Reagents}

All chemicals were of analytical grade and were used without further purification. All solutions were made with a mixture of bidistilled, deionised and carbon dioxide-free water (30\%, vol./vol.) and ethanol ( $70 \%)$ from Merck (Brazil). VitD (cholecalciferol) was purchased from Sigma-Aldrich (France). Solutions were freshly prepared prior to their use.

The solutions of zinc(II) were obtained from nitrate (Carlo-Erba, Brazil) salt and quantified by complexometric titration [4]. Those of manganese(II) chloride were made by appropriate dilutions of Titrisol ${ }^{\mathrm{TM}}$ (Merck). Anhydrous $\mathrm{FeCl}_{3}$ (Merck) and $\mathrm{Fe}\left(\mathrm{ClO}_{4}\right)_{2} \cdot 2 \mathrm{H}_{2} \mathrm{O}$ (GFS Chemicals, USA) were manipulated under inert atmosphere and were weighed in the solid state. The carbonate-free $\mathrm{KOH}$ solutions $(0.100 \mathrm{M})$ were standardised against potassium hydrogeno- 
phthalate. In all experiments, the ionic strength $(\mu)$ was maintained at $0.100 \mathrm{M}$ by using $\mathrm{KNO}_{3}$ (Baker and Adamson, USA) as supporting electrolyte.

The ligand solution was transferred into the reaction vessel and was titrated with the $\mathrm{KOH}$ solution, first in the absence of metal ion and then in its presence. The numbers of moles of vitD, $\mathrm{Fe}^{2+}$ and $\mathrm{Fe}^{3+}$ were calculated taking into account their actual weighed mass.

\subsection{Method}

The potentiometric titrations were carried out under inert atmosphere using $0.100 \mathrm{M} \mathrm{KOH}$ water-ethanol solutions (saturated with dinitrogen) with continuous magnetic stirring and under a purified dinitrogen flow (White-Martins, Brazil) in a $60 \mathrm{ml}$ jacketed vessel at $25.0 \pm 0.1^{\circ} \mathrm{C}$ (Microquimica MQBTC 99-20) with an airtight cap fitted with gas inlet and outlet tubes, glass and calomel reference electrodes (Analyser, Brazil). The $\mathrm{p} K_{\mathrm{w}}$ of water in this water-ethanol medium was determined by potentiometric titration of waterethanol (30/70\% vol./vol.) and the determined value, mean of five experiments, was $14.71 \pm 0.02[3,5]$. A $20 \mathrm{ml}$ Metrohm manual piston burette was used to deliver the titrant, standard $\mathrm{CO}_{2}$-free $\mathrm{KOH}$ solution, and the $\mathrm{p}[\mathrm{H}]$ values $\left(\mathrm{p}[\mathrm{H}]=-\log _{10}\left[\mathrm{H}^{+}\right]\right.$, a specie between square brackets denotes its molarity) were directly measured with a Micronal B-375 model pHmeter (SP, Brazil). The pHmeter was calibrated with standard adjusted ionic strength $(0.100 \mathrm{M}$, $\left.\mathrm{KNO}_{3}\right) \mathrm{HCl}$ in water-ethanol (30/70\% vol./vol.) solution before starting the titration. The slope of the response of the glass electrode was determined by using the data obtained from a potentiometric titration of a known volume of this standard $0.100 \mathrm{M}$ in water-ethanol (30/70\%, vol./vol.) $[3,5,6]$.

VitD was kept under inert atmosphere in a Schlenke glass and was always transferred to the reaction vessel using another Schlenke glass stopped with Suba-Seal (Sigma, USA) inside a glove bag (Sigma). About $40 \mathrm{mg}$ of vitD ( 0.1 mol) was dissolved in $10 \mathrm{ml}$ absolute ethanol p.a. and then transferred via a syringe to the titration vessel, previously prepared with all other reactants and under inert atmosphere. When investigating $\mathrm{Fe}^{2+}$ and $\mathrm{Fe}^{3+}$ ions, their salts were transferred inside a glove bag from a Schlenke glass to another one stopped with Suba-Seal and, after being weighed ( 0.1 and $0.05 \mathrm{~mol}$ approximately), they were dissolved in 4 $\mathrm{ml}$ of absolute ethanol and taken into the reaction vessel via another syringe prior to the transfer of vitD. All volumes of ethanol used to dissolve the reactants were taken into account in the calculation of solvent percentages.

Each potentiometric titration of approximately $0.1 \mathrm{mmol}$ of vitD with 0.1 and $0.05 \mathrm{mmol}$ each of the studied metallic cations was carried out three times. All titrations were made after stabilisation of the first $\mathrm{p}[\mathrm{H}]$ value of the system which was achieved by the successive additions of $0.04 \pm 0.02 \mathrm{ml}$ and $0.06 \pm 0.02 \mathrm{ml}$ of titrant. The corresponding $\mathrm{p}[\mathrm{H}]$ was read and plotted to calculate the values of the overall forma- tion constants of the systems. All titrations were carried out in the presence of $\mathrm{HNO}_{3}$ (Merck) in $30 \% \mathrm{H}_{2} \mathrm{O}-70 \%$ ethanol (vol./vol.) solutions of about $0.8 \mathrm{M}$, determined by Gran's plot. This ensured that the titrations would start from $\mathrm{p}[\mathrm{H}]$ values under 3.0 . The titration of this strong additional acid is represented by points plotted in the negative range of the $x$ axis in Fig. 1.

\subsection{Data treatment}

All equilibrium constants were calculated using the microcomputer program Best 7. All mathematical details have been previously described [3,5-8].

Mole and millimole units were used to express the quantities of reagents, and the hydrolysis constants in the present solvent for all the metal ions studied were obtained from the literature [9] and were fully employed in all calculations.

The species distribution curves were drawn with the microcomputer program SPE [5-8]. In general, three titrations were made: one with the ligand alone and two others with ligand and metals in various metal-to-ligand ratios. These ratios were chosen in such a way as to favour the formation of $1: 1$ and $1: 2$ complex species (ML and $\mathrm{ML}_{2}$ respectively) where $M$ is the metal ion and $L$ the $O H$ deprotonated vitD. The solution of vitD and $\mathrm{Fe}^{3+}$ in a $1: 3$ ratio at $1 \times 10^{-3} \mathrm{M}$ could not be made because of the low solubility of this system at low $\mathrm{p}[\mathrm{H}]$ values. All reported results are the average of three potentiometric titration experiments.

\section{Results and discussion}

The average overall apparent formation constants $\beta_{n}$ were obtained as follows from the stepwise equilibrium:

$$
\begin{aligned}
& \mathrm{M}+\mathrm{L} \rightleftharpoons \mathrm{ML} \text { with: } \beta_{1}=\frac{[\mathrm{ML}]}{[\mathrm{M}][\mathrm{L}]} \\
& \mathrm{ML}+\mathrm{H} \rightleftharpoons \mathrm{MLH} \text { with: } \beta_{\mathrm{H}}=\frac{[\mathrm{MLH}]}{[\mathrm{ML}][\mathrm{H}]} \\
& \mathrm{ML}+\mathrm{L} \rightleftharpoons \mathrm{ML}_{2} \text { with: } \beta_{2}=\frac{\left[\mathrm{ML}_{2}\right]}{[\mathrm{M}][\mathrm{L}]^{2}} \\
& \mathrm{ML}_{2}+\mathrm{L} \rightleftharpoons \mathrm{ML}_{3} \text { with: } \beta_{3}=\frac{\left[\mathrm{ML}_{3}\right]}{[\mathrm{M}][\mathrm{L}]^{3}}
\end{aligned}
$$

where $M$ is the metal ion and $L$ the deprotonated vitD, $\operatorname{VitD}\left(\mathrm{O}^{-}\right)$. In this solvent, the value of the protonation constant for the hydroxyl group in vitD is $\log K=12.4$ [ 10]:

$\mathrm{VitD}\left(\mathrm{O}^{-}\right)+\mathrm{H}^{+} \rightleftharpoons \mathrm{VitD}$

or

$\mathrm{L}+\mathrm{H} \rightleftharpoons \mathrm{HL}$

Fig. 1 depicts the potentiometric $\mathrm{p}[\mathrm{H}]$ profiles for each titration of vitD ( 13 points) with $\mathrm{Mn}^{2+}$ ( 12 and 15 points), 

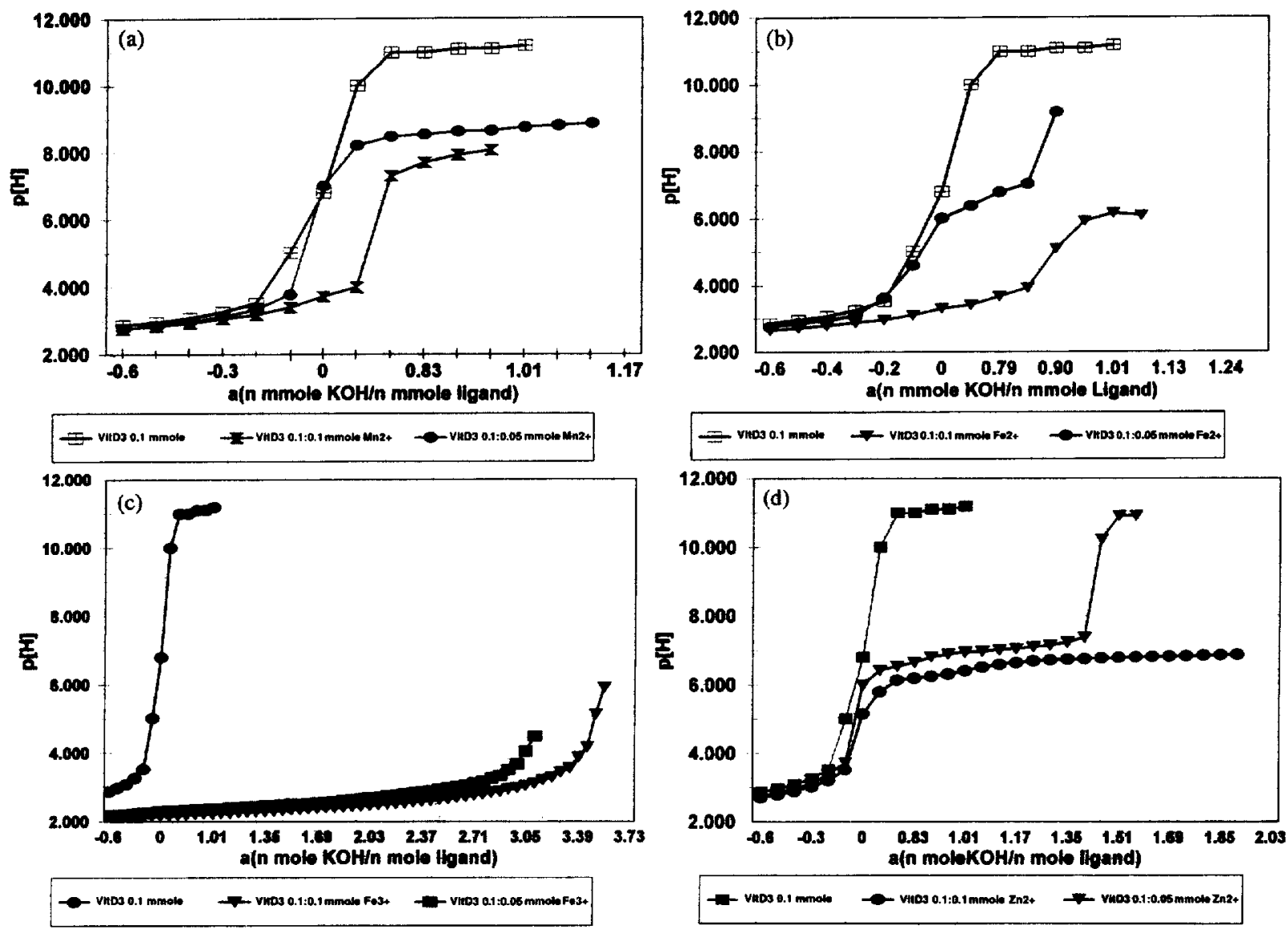

Fig. 1. Potentiometric ( $\mathrm{p}[\mathrm{H}]$ ) profiles of $0.1 \mathrm{mmol}$ of vitD and 0.1 and $0.05 \mathrm{mmol}$ of (a) manganese(II), (b) iron(II), (c) iron(III) and (d) zinc(II).

$\mathrm{Fe}^{2+}$ ( 11 and 14 points), $\mathrm{Fe}^{3+}\left(50\right.$ and 57 points) and $\mathrm{Zn}^{2+}$ ( 23 and 29 points) respectively. They show that in all cases, irrespective of metal-to-ligand ratio and cation, these systems undergo rapid hydrolysis and solvolysis, preventing, in some cases, the determination of the formation constants of the complex species. Higher ratios of ligand-to-metal titrations did not prevent this immediate hydrolysis and solvolysis.

Fig. 1 shows that there is a strong depletion in the values of $\mathrm{p}[\mathrm{H}]$ when the ligand is in the presence of metal ions. The titration curves for $\mathrm{Mn}^{2+}$ complexes show an inflexion point at $a=3.0$ ( 3.0 base equivalent) and at $0.85,3.4$ and 1.4 respectively for $\mathrm{Fe}$ (II), $\mathrm{Fe}$ (III) and $\mathrm{Zn}$ (II).

Table 1 summarises the logarithms of the stability constants for all the complex species detected by potentiometric titrations calculated on the basis of the equilibria (1) to (5), taking care to avoid the formation of hydroxo and/or solvo complexes. The formation constants of $1: 1,1: 2$ and $1: 3$ metalto-ligand ratio complexes were evaluated from the $\mathrm{p}[\mathrm{H}]$ profiles for solutions containing 1:1 and 1:2 molar stoichiometry of cation to ligand. The species under investigation were those

Table I

Logarithmic values ${ }^{a}$ for the formation constants of the complexes of vitD with $\mathrm{Mn}^{2+}, \mathrm{Fe}^{2+}, \mathrm{Fe}^{3+}$ and $\mathrm{Zn}^{2+}$ ions at $298 \mathrm{~K}$ ( $\beta=$ overall stability constant; $K=$ stepwise stability constant)

\begin{tabular}{lllll}
\hline & Manganese(II) & Iron(II) & Iron(III) & Zinc(II) \\
\hline $\log K_{1}=\log \beta_{1}$ & $6.6 \pm 0.1$ & $8.5 \pm 0.1$ & $15.5 \pm 0.1$ & $8.8 \pm 0.3$ \\
$\log K_{\mathrm{H}}$ & n.d. & n.d. & $3.0 \pm 0.1$ & n.d. \\
$\log K_{2}$ & $5.8 \pm 0.1$ & $8.0 \pm 0.1$ & $13.0 \pm 0.1$ & $7.7 \pm 0.3$ \\
$\left(\log \beta_{2}\right)$ & $(12.4)$ & $(16.5)$ & $(28.5)$ & $(16.5)$ \\
$\log K_{3}$ & n.d. & n.d. & $6.2 \pm 0.1$ & n.d. \\
$\left(\log \beta_{3}\right)$ & & & $(34.7)$ & \\
\hline
\end{tabular}

${ }^{a}$ n.d. $=$ not detected. 
expected according to common principles of coordination chemistry.

$\mathrm{ML}_{3}$ species were only detected in the presence of the strong Lewis acid $\mathrm{Fe}^{3+}$, which is able to deprotonate and hold a third molecule of vitD. Although there was formation of insoluble products at $\mathrm{p}[\mathrm{H}]$ values of about 6.0 , there was not enough concentration of $\mathrm{ML}_{3}$ species to be detected by potentiometric titration.

Figs. 2-5 depict the distribution diagrams for the formation constants obtained from saturated solutions with vitD and $\mathrm{Mn}^{2+}, \mathrm{Fe}^{2+}, \mathrm{Fe}^{3+}$ and $\mathrm{Zn}^{2+}$ respectively, with the metal ion concentration set at $100 \%$ and calculated from $\mathrm{p}[\mathrm{H}]=2$ to 12. These diagrams show the maximum formation of the complex species ML between vitD and the metallic ion for a $\mathrm{p}[\mathrm{H}]$ value of $9.0\left(\mathrm{Mn}^{2+}\right), 7.0\left(\mathrm{Fe}^{2+}\right), 3.0\left(\mathrm{Fe}^{3+}\right)$ and 7.0 $\left(\mathrm{Zn}^{2+}\right)$. The maximum formation of $\mathrm{ML}_{2}$ complexes occurred at $\mathrm{p}[\mathrm{H}]=12.0$ for $\mathrm{Mn}^{2+}, 10.0$ for $\mathrm{Fe}^{2+}, 6.0$ for $\mathrm{Fe}^{3+}$ and 11.3 for $\mathrm{Zn}^{2+}$. Finally, the maximum formation of the complex $\mathrm{ML}_{3}$ with $\mathrm{Fe}^{3+}$ is located at $\mathrm{p}[\mathrm{H}]=10$.

The metal ions $\mathrm{Fe}^{2+}$ and $\mathrm{Fe}^{3+}$ show some complex species throughout the range of $\mathrm{p}[\mathrm{H}]$ under study, despite the formation of metal hydroxide precipitates at $\mathrm{p}[\mathrm{H}]$ values below

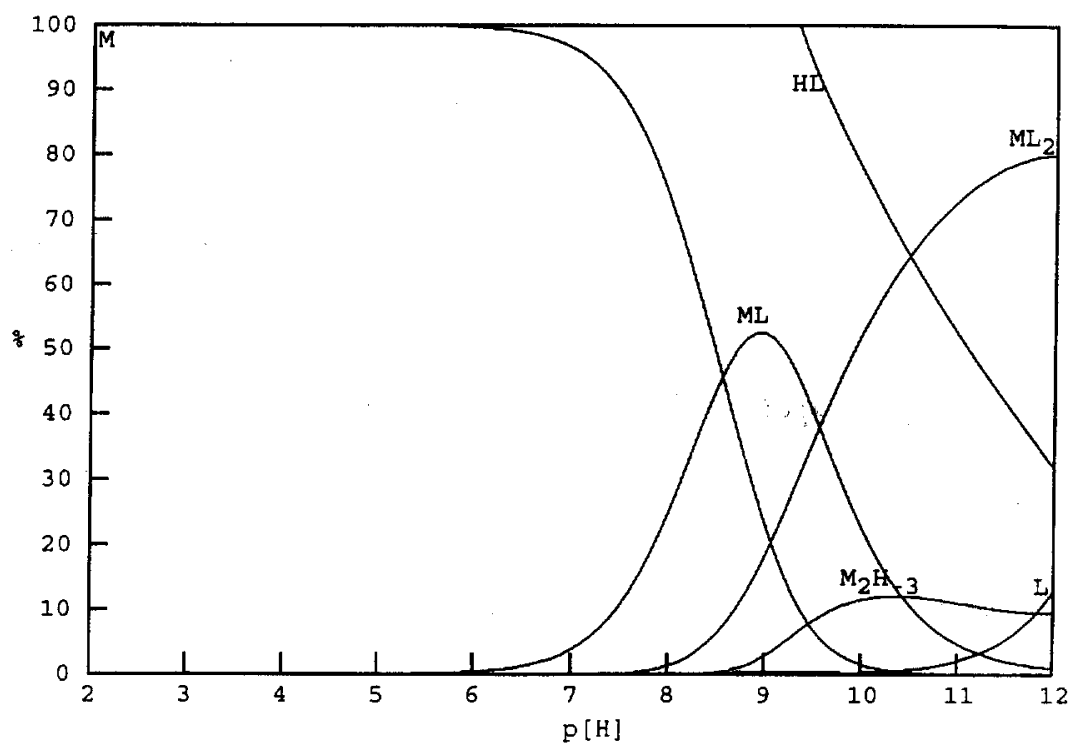

Fig. 2. Species distributions of solutions of vitD $(\mathrm{L})\left(2.5 \times 10^{-3} \mathrm{M}\right)$ and $\mathrm{Mn}^{2+}(\mathrm{M})\left(2.50 \times 10^{-3} \mathrm{M}\right)$ for $\mathrm{p}[\mathrm{H}]$ values from 2.0 to 12.0 . The metal concentration is set at $100 \%, \mathrm{H}_{-x}$ indicates $\left[\mathrm{OH}^{-}\right]_{x}$.

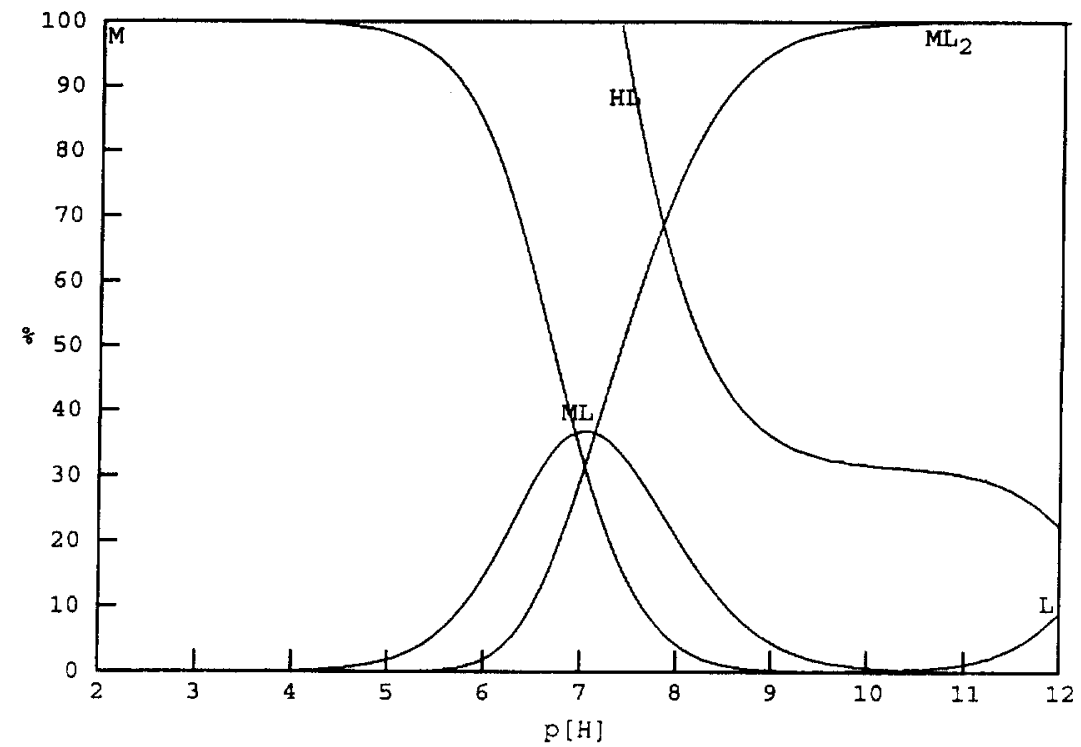

Fig. 3. Species distributions of saturated solutions of vitD $\left(2.5 \times 10^{-3} \mathrm{M}\right)$ and $\mathrm{Fe}^{2+}\left(2.50 \times 10^{-3} \mathrm{M}\right)$ for $\mathrm{p}[\mathrm{H}]$ values from 2.0 to 12.0 . 


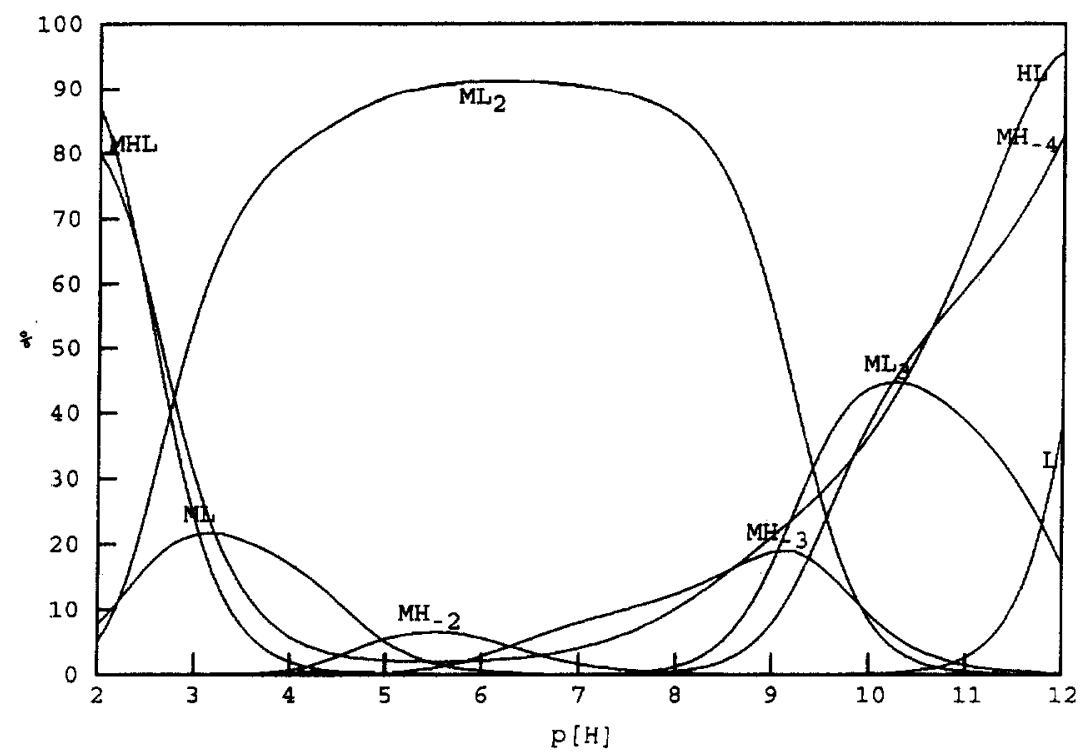

Fig. 4. Species distributions of saturated solutions of vitD $\left(2.5 \times 10^{-3} \mathrm{M}\right)$ and $\mathrm{Fe}^{3+}\left(2.50 \times 10^{-3} \mathrm{M}\right)$ for $\mathrm{p}[\mathrm{H}]$ values from 2.0 to 12.0 . The metal concentration is set at $100 \% \cdot \mathrm{H}_{-x}$ indicates $\left[\mathrm{OH}^{-}\right]_{x}$.

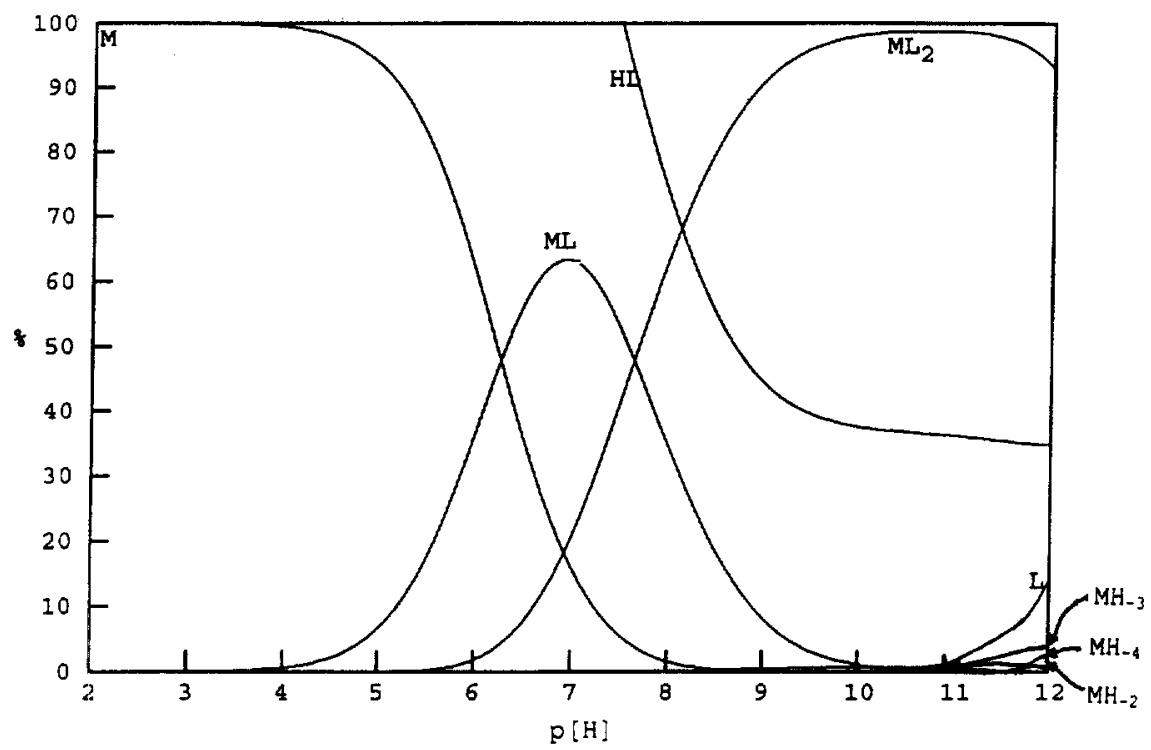

Fig. 5. Species distributions of saturated solutions of vitD $\left(2.5 \times 10^{-3} \mathrm{M}\right)$ and $\mathrm{Zn}^{2+}\left(2.50 \times 10^{-3} \mathrm{M}\right)$ for $\mathrm{p}[\mathrm{H}]$ values from 2.0 to 12.0 . The metal concentration is set at $100 \%, \mathrm{H}_{-x}$ indicates $\left[\mathrm{OH}^{-}\right]_{x}$.

or near neutral values. The metal ions $\mathrm{Mn}^{2+}$ and $\mathrm{Zn}^{2+}$ form stable complexes above $\mathrm{p}[\mathrm{H}]$ values of 7.0 and 5.0, respectively.

$\mathrm{Fe}^{3+}$ ions led to the highest stability constants in this series (Table 1). This indicates that there is no steric hindrance in this species for which the maximum formation is centred around $\mathrm{p}[\mathrm{H}]=10.2$.

Fig. 6 shows the relation between the first stability constant $K_{1}$ relative to equilibrium (1) and the atomic number of the metal used in this study and in our previous paper [3]. It may be remarked here that the tendency of the curve shows that copper( II) leads to the highest stability of the complex. This follows the well-known Irving-Williams series [11] with the exception of the complex with $\mathrm{Fe}^{2+}$. The progression of this series in alcoholic medium has been recently verified for the metal ions under consideration [12] and has been explained on the basis of the second ionisation potential of the ions. It has been shown to be valid equally in the case of dog, bovine and human serum albumin complexing copper(II) and zinc(II) $[13,14]$. Though our experiments were performed under inert atmosphere to prevent ferrous ions from oxidation, the high value of $K_{1}$ in the case of $\mathrm{Fe}^{2+}$ could be explained on the basis of an equilibrium between $\mathrm{Fe}$ (II) and Fe(III) ions. 


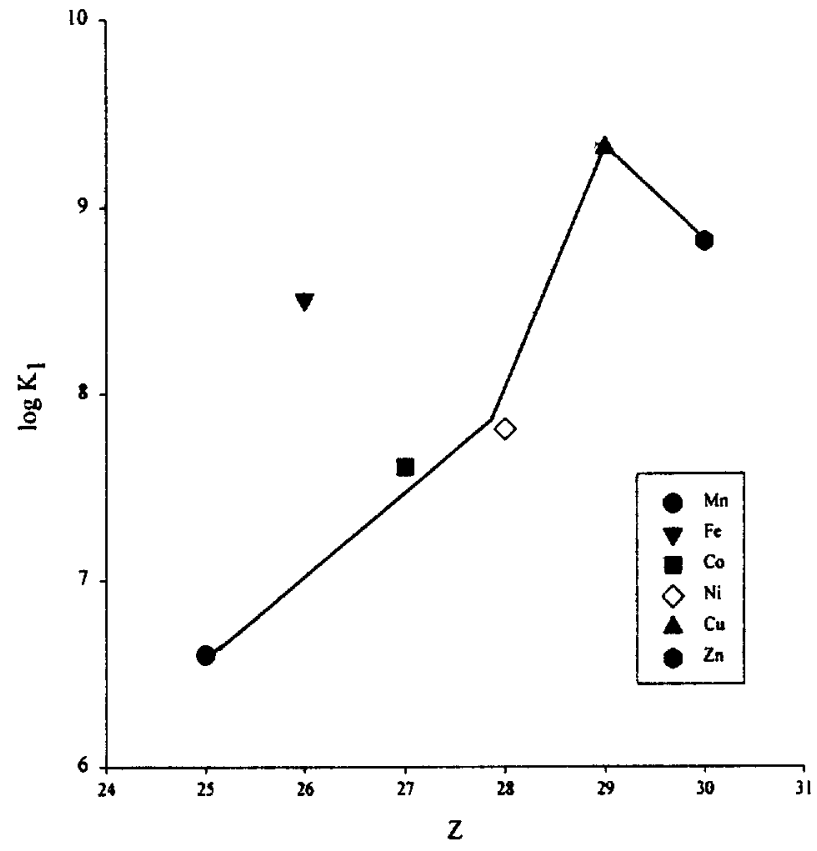

Fig. 6. Logarithms of the first stability constant for some divalent cations.

\section{Acknowledgements}

The authors thank the sponsor Universidade Federal do Paraná, UFPR, Brazil.

\section{References}

[1] J.A. Cowan, Chem. Rev. 98 (1998) 1067.

[2] J.E. Coleman, K.I. Nakamura, J.F. Chlebowski, J. Biol. Chem. 258 (1983) 386.

[3] A.L.R. Mercê, B. Szpoganicz, R.C. Dutra, M.A. Khan, X. Do Thanh, G. Bouet, J. Inorg. Biochem. 71 (1998) 87.

[4] G. Schwarzenbach, H. Flaschka, Complexometric Titrations, Methuen, London, 1969, p. 256.

[5] E.W. Schwingel, K. Arend, J. Zarling, A. Neves, B. Szpoganicz, J. Braz. Chem. Soc. 7 ( 1996) 31.

[6] A.E. Martell, R.J. Motekaitis, The Determination and Use of Stability Constants, 2nd ed., VCH, New York, 1992.

[7] Y.J. Li. A.E. Martell, Inorg. Chim. Acta 214 (1993) 103.

[8] R. Delgado, Y. Sun, R.J. Motekaitis, A.E. Martell, Inorg. Chem. 32 (1993) 3320.

[9] C.F. Baes Jr., R.E. Mesmer, The Hydrolysis of Cations, Wiley, New York, 1976.

[10] A.E. Martell, R.M. Smith, NIST Critical Stability Constants of Metal Complexes, NIST Database, 46, Gaithersburg, MD, USA, 1994.

[11] H. Irving, R.J.P. Williams, J. Chem. Soc. (1953) 3192.

[12] M. Khan, G. Bouet, F. Vierling, J. Meullemeestre, M.J. Schwing, Transition Met. Chem. 21 (1996) 213.

[13] J. Masuoka, J. Hegenauer, B.R. Van Dyke, P. Saltman, J. Biol. Chem. 268 (1993) 21553

[14] J. Masuoka, P. Saltman, J. Biol. Chem. 269 (1994) 25557. 